\title{
The Effect of Instructional Models and Mathematical Logic Intelligence toward the Basic Chemistry Learning Outcomes by Controlling Student's Initial Competence
}

\author{
Aceng Haetami*, Mohamad Syarif Sumantri, Priyono \\ Graduate School of Education Technology, Universitas Negeri Jakarta, Indonesia
}

Received December 25, 2019; Revised January 23, 2020; Accepted February 7, 2020

Copyright $\bigcirc 2020$ by authors, all rights reserved. Authors agree that this article remains permanently open access under the terms of the Creative Commons Attribution License 4.0 International License

\begin{abstract}
The objectives of this research were to determine the effects of instructional models and mathematical logic intelligence on primary chemistry learning outcomes with initial competence as a covariate variable. This research conducted at the department of chemistry education in the Faculty of Teacher Training and Education, Halu Oleo University Kendari from Maret to June 2018 and used a quasi-experimental method with a $2 \times 2$ by level design. A sample of 56 students was random. ANCOVA and T-Test ANCOVA applied to analyze the data obtained at a significant level of 0,05 . The results indicate that: (1) the basic chemistry learning outcomes of students were taught to use concept attainment model was better than direct instruction model by controlling the initial competence; (2) there was an interaction between instructional models and mathematical logic intelligence on basic chemistry learning outcomes by controlling the initial competence; (3) the basic chemistry learning outcomes of students with higher mathematical logic intelligence taught to use concept attainment model were higher than direct instruction model by controlling the initial competence; (4) there was no significant differences between the basic chemistry learning outcomes of students with mathematical logic intelligence taught to use concept attainment models by being taught direct instruction model by controlling initial competence.
\end{abstract}

Keywords Direct Instruction, Mathematical Logic Intelligence, Initial Competence, Primary Chemistry Learning Outcomes

\section{Introduction}

One of the main tasks of educators is to provide the best for students in the learning process, more specifically in transferring knowledge to students, using appropriate learning models. The learning model is a systematic and planned way presented by educators in implementing the learning process so that the accuracy of the selection of learning models by educators also determines the success of achieving learning objectives [1]. Educators should be able to choose learning models that fit the characteristics of the material and students [2]. However, in reality, many educators have difficulty choosing the right learning model in the learning process. Educators generally trapped by the word "transferring knowledge to students" so that in the learning process, educators only cram students with a variety of relevant lecture material by the curriculum. Learning is more center on educators; students only listen and take notes, so students are passive. This certainly not surprising if the current learning outcomes of students are on average, not as expected.

The low student learning outcomes, as explained above, are also experienced by students majoring in chemistry education Faculty of Teacher Training and Education Halu Oleo University, especially in basic chemistry courses. Basic chemistry courses are the focus of researchers' attention because basic chemistry is a subject that is the main foundation for the mastery of further chemical materials. The average learning outcomes of basic chemistry for the last 3 (three) years is always below 60 . For example, to basic chemistry course 2 for the 2014/2015 Academic year with an average of 56,71 with a distribution of grades of $5,43 \% \mathrm{~A} ; 51,58 \% \mathrm{~B}$; and $42,99 \% \mathrm{C}$. On the $2015 / 2016$ Academic year with an average of 56,63 with a distribution value of $4,59 \% \mathrm{~A} ; 47,12 \% \mathrm{~B}$; and $48,29 \% \mathrm{C}$. While the 2016/2017 Academic year with a mean of 58,41 with a distribution of $6,82 \% \mathrm{~A} ; 44,32 \% \mathrm{~B}$; and $48,86 \% \mathrm{C}$. It explains that the results of learning basic chemistry 2 are not in line with expectations and are considered inadequate. 
The results of learning basic chemistry 2, of course, show that the quality of basic chemistry learning at Faculty of Teacher Training and Education Halu Oleo University needs to immediately address by referring to the root problems that occur in the classroom. The results of the reflection with the team of the primary chemistry instructor of the Department of Chemistry, Faculty of Teacher Training and Education Halu Oleo University, revealed that several things caused the low learning outcomes of basic chemistry : (1) During this time, necessary chemistry lecturers carry out learning using direct learning models that are centered only with lecturers, lecturers provide material systematically and gradually, students listen and take notes, there is no interaction in the classroom both between lecturers and students and between students and students, As a result, student learning outcomes from year to year have not improved, (2) necessary chemistry lecturers do not check the initial abilities of each student, so they cannot identify the learning readiness of each student, (3) essential chemistry lecturers do not pay attention that student abilities vary greatly both in terms of individual potential and student learning experiences, (4) necessary chemistry lecturers do not provide training with analytical questions and synthesis so that students' critical thinking skills are less explored. From the results of these reflections, it said can be that in learning basic chemistry, chemistry lecturers at the Faculty of Mathematics and Natural Sciences Halu Oleo University less involve students in active learning. Consequently, their learning motivation is shallow and in turn, leads to low learning outcomes.

The results of the research by [3], [4] find that learning that includes active students can improve: 1) motivation and interest in education, 2) interaction between educators and students, 3) critical thinking skills and problem-solving, and 4) student performance The results of the research above show that learning models that actively involve students in learning will be able to improve the ability of students in thinking, to work, and being scientific.

One of the efforts offered by researchers that expected to improve the quality of learning in the classroom is to apply the concept learning model. The concept achievement learning model is designed to analyze concepts, develop concepts, gain ideas, and to help students become more effective in learning theories, so students will be elementary to understand the concepts [5]. Concept achievement learning models are efficient models for presenting related information from a broad topic becomes a topic that is easier to know for each stage of concept development. The concept achievement learning model can provide a way to communicate concepts and clarify concepts and train students to be more effective in learning concepts so that student learning outcomes are expected to increase.

Kumar and Mathur's [6] explain that there are significant differences between the concept achievement learning model (CAM) and the traditional learning model (TM) towards the students' achievement in understanding physics concepts. [7][8] found that learning with the learning model of achieving ideas was more effective in improving learning outcomes in geometry compared to conventional learning models. [9] confirms that the application of the concept achievement learning model is more effective than traditional learning characterized by 1) there is an increase in accuracy and skills in letter writing; 2) there is an increase in students ability to identify sounds, and 3) there is an increase in efficiency and ability to pronounce the letters and target words.

Furthermore, the results [10] confirm that the learning achievement of students in social science taught through the concept achievement model is higher than the learning achievement of students taught through traditional methods. In this study, the potential factors of intelligence of students not considered, so it is necessary to research the application of the achievement of concepts based on the potential of students' knowledge. [11] in his study, found that the useful concept learning achievement model used was as a training strategy to train workers about chemical information and health hazards. Then [12][13]showed that there were significant differences in the average score of biology posttest between the experimental group (concept learning model) with a mean of 61,67 and a control group with a way of 51,6.

Based on the results of previous studies, it can be concluded that the application of the concept learning model is very useful in improving student learning outcomes. In the concept learning model, students are required to have the ability to analyze concepts, test, and provide hypotheses, so that the lecturer must identify the intelligence potential of students. Every human being has a potential intelligence called compound intelligence. Each student has a particular tendency (dominant) from the possible information he has. One of the intelligence potentials of students is mathematical, logical intelligence[14]. The basis of precise, consistent information emphasizes thinking activities that are measurable, quantitative, and analysis. In this mathematical intelligence-based learning emphasizes the ability in reasoning, educating, thinking in causal patterns, creating hypotheses, looking for conceptual regularities or numerical models, characterizing something based on cause and effect, grouping, through a process of classification or identification [15].

Based on the description, it can be said that it is essential to study whether the learning model of the achievement of concepts and mathematical intelligence affect the learning outcomes of students. In addition, treatment in learning, one of the factors that are thought to impact student learning outcomes, is the very new ability of students of Faculty of Teacher Training and Education Halu Oleo University in chemistry education, which is very diverse. Therefore, in this study, student's fundamental skills are 
controlled so that their effects on learning outcomes can be minimized.

\section{Materials and Method}

One of the main tasks of educators is to provide the best for the method used in this study is quasi-experimental. The research variables measured in this study involve two main variables, namely the independent variable and the dependent variable. The dependent variable is the basic chemistry learning outcomes and the independent variable consists of two variables, namely: (a) the treatment variable consisting of the concept learning achievement model $\left(\mathrm{A}_{1}\right)$ and the direct learning model $\left(\mathrm{A}_{2}\right)$, (b) the mathematical moderator variable, logical intelligence consisting of intelligence high mathematical logic $\left(\mathrm{B}_{1}\right)$ and low mathematical logic $\left(B_{2}\right)$.

A sampling of this study was carried out by a random sampling technique. The technique used because the sampling of members of the population is done randomly without regard to levels in the community[16]. The sample selection for the experimental class and the control class made by drawing from two parallel types (class A and class B). Before being given treatment to both levels, students are first given an initial ability test and a mathematical logic intelligence test using a validated instrument. Then from the results of numerical, logical intelligence tests sorted from the highest score (top rank) to the lowest score (bottom rank). Determination of groups of students who have high and low mathematical, logical intelligence in this study used the division of $27 \%$ top groups and $27 \%$ small groups as samples[17].

Based on this division, for the experimental class which amounted to 54 people, obtained high and low mathematical, logical intelligence groups respectively standing to $27 \% \times 54$ people $=14$ people and for the control, class totaling 53 people Obtained by high and low mathematical logical intelligence groups respectively amounting to $27 \%$ x 53 people $=14$ people. Thus the experimental class and the control class each amounted to 14 people.

The design of this study uses Design Treatment by Level 2 X 2 As presented in Table 1.

Table I. Quasi-experimental design treatment by level $2 \times 2$

\begin{tabular}{|c|c|c|}
\hline \multirow{2}{*}{ Moderator Variable } & \multicolumn{2}{|c|}{ Treatment Variables } \\
\cline { 2 - 3 } & $\begin{array}{c}\text { Concept Attainment } \\
\text { Model (A1) }\end{array}$ & $\begin{array}{c}\text { Direct } \\
\text { Instruction } \\
\text { Model (A2) }\end{array}$ \\
\hline $\begin{array}{c}\text { High Mathematical } \\
\text { Logic Intelligence (B1) }\end{array}$ & A1B1(14) & A2B1(14) \\
\hline $\begin{array}{c}\text { Low Mathematical } \\
\text { Logic Intelligence (B2) }\end{array}$ & A1B2(14) & A2B2(14) \\
\hline Total & 28 & 28 \\
\hline
\end{tabular}

Test data analysis requirements used are the UI normality test, the homogeneity test, the linearity test, the significance of the regression effect test, and the line alignment test. Testing the research hypothesis is done through covariate analysis (ANCOVA).

\section{Results}

The results of the description of the data on the primary chemistry learning outcomes of the chemistry education study program at Halu Oleo University as shown in Table 2.

The results of the covariance analysis to test the differences chemistry learning outcomes between groups of students taught who with the learning model of achieving concepts and were prepared those who with the direct learning model $\left(A_{1}-A_{2}\right)$ presented are in Table 3 . 
Table 2. Descriptive analysis of data from research results

\begin{tabular}{|c|c|c|c|c|c|}
\hline \multirow{3}{*}{\multicolumn{2}{|c|}{ (B) }} & \multicolumn{4}{|c|}{ Learning model (A) } \\
\hline & & \multicolumn{2}{|c|}{ Achievement of Concepts $\left(A_{1}\right)$} & \multicolumn{2}{|c|}{ Directly $\left(\mathrm{A}_{2}\right)$} \\
\hline & & $\begin{array}{c}\text { Initial } \\
\text { Ability }(\mathrm{X})\end{array}$ & Learning outcomes $(\mathrm{Y})$ & $\begin{array}{c}\text { Initial } \\
\text { Ability }(\mathrm{X})\end{array}$ & Learning outcomes $(\mathrm{Y})$ \\
\hline \multirow{6}{*}{$\begin{array}{l}\mathrm{B}_{1} \\
\text { (High) }\end{array}$} & $\mathrm{N}$ & 14 & 14 & 14 & 14 \\
\hline & Average & 81,36 & 85,71 & 79,71 & 65,86 \\
\hline & Median & 82 & 86 & 81 & 66 \\
\hline & Maximum & 88 & 92 & 85 & 79 \\
\hline & Minimum & 72 & 79 & 68 & 55 \\
\hline & Standard deviation & 5,05 & 3,52 & 4,87 & 6,64 \\
\hline \multirow{6}{*}{$\begin{array}{l}\mathrm{B}_{2} \\
\text { (Low) }\end{array}$} & $\mathrm{N}$ & 14 & 14 & 14 & 14 \\
\hline & Average & 66,29 & 64,29 & 66,21 & 72,86 \\
\hline & Median & 66,5 & 65 & 64 & 72,5 \\
\hline & Maximum & 77 & 74 & 82 & 83 \\
\hline & Minimum & 56 & 48 & 58 & 60 \\
\hline & Standard deviation & 5,61 & 6,97 & 7,58 & 6,26 \\
\hline \multicolumn{2}{|l|}{$\mathrm{N}$} & 28 & 28 & 28 & 28 \\
\hline \multicolumn{2}{|c|}{ Average } & 73,82 & 75,00 & 72,96 & 69,36 \\
\hline \multicolumn{2}{|l|}{ Median } & 72,5 & 76,5 & 75 & 70 \\
\hline \multicolumn{2}{|c|}{ Maximum } & 88 & 92 & 85 & 83 \\
\hline \multicolumn{2}{|c|}{ Minimum } & 56 & 48 & 58 & 55 \\
\hline \multicolumn{2}{|c|}{ Standard deviation } & 9,29 & 12,18 & 9,29 & 7,27 \\
\hline
\end{tabular}

Table 3. Covariance analysis table

\begin{tabular}{|c|c|c|c|c|c|}
\hline \multicolumn{7}{|c|}{ Tests of Between-Subjects Effects } \\
\hline \multicolumn{2}{|c|}{ Dependent Variable: Y } & Mean Square & F & Sig. \\
\hline Source & Type III Sum of Squares & Df & 1262,187 & 77,606 &, 000 \\
\hline Corrected Model & $5048,750^{\mathrm{a}}$ & 4 & 86,586 & 5,324 &, 025 \\
\hline Intercept & 86,586 & 1 & 1045,678 & 64,294 &, 000 \\
\hline X & 1045,678 & 1 & 346,434 & 21,301 &, 000 \\
\hline A & 346,434 & 1 & 73,496 & 4,519 &, 038 \\
\hline B & 73,496 & 1 & 2582,584 & 158,791 &, 000 \\
\hline A * B & 2582,584 & 51 & 16,264 & & \\
\hline Error & 829,464 & 56 & & & \\
\hline Total & 297624,000 & 55 & & & \\
\hline Corrected Total & 5878,214 & & & \\
\hline
\end{tabular}

Based on the results of the calculation of the covariance analysis Table 3 , a value is obtained $F_{\text {count }}\left(F_{0}\right)=21,301$ and $\mathrm{Ft}_{(0.05 ; 3 / 51)}=4,08 . \mathrm{F}_{\text {count }}$ results that are greater than $\mathrm{F}_{\text {tables }}, \mathrm{F}_{0}$ $(21,301)>\mathrm{Ft}_{(0.05 ; 1 / 40)}(4.08)$ show that there are differences in essential Chemistry Learning Outcomes between groups of students are taught with the Concept Learning Achievement Model and those Learned with the Direct Learning Model, after controlling the initial abilities of students.

Based on the results of the descriptive analysis in Table 4, it was obtained that $\mathrm{Y}_{\mathrm{A} 1}=75,00$ and $\mathrm{Y}_{\mathrm{A} 2}=69,36$ so that the hypothesis $\mathrm{H}_{1}: \boldsymbol{\mu}_{\boldsymbol{A} \boldsymbol{I}}>\boldsymbol{\mu}_{\boldsymbol{A} \boldsymbol{2}}$ accepted. Which means that the essential chemistry learning outcomes of student groups taught with the Concept Learning Model Achievement is higher than the basic chemistry learning outcomes of student groups that shown are with the Direct Learning Model, after controlling the student's initial ability.

The results of the analysis of variants to test the effect of interactions between learning models and mathematical presented are logical intelligence on learning outcomes of basic chemistry in Table 4.

Based on Table 4 it can be seen that the value of $\mathrm{F}_{0}$ $(63,006)>\mathrm{Ft}_{(0.05 ; 3 / 51)}(2.85)$, this rejected is means that $\mathrm{H}_{0}$, so that there is an interaction effect between learning models and mathematical, logical intelligence on essential chemistry learning outcomes, after controlling the ability student beginnings which visually explained can be through Figure 1. 
The Effect of Instructional Models and Mathematical Logic Intelligence

toward the Basic Chemistry Learning Outcomes by Controlling Student's Initial Competence

Table 4. Analysis of variance of interaction between treatment groups

\begin{tabular}{|c|c|c|c|c|c|c|}
\hline \multicolumn{7}{|c|}{ Tests of Between-Subjects Effects } \\
\hline Source & Type III Sum of Squares & Df & Mean Square & F & Sig. & Partial Eta Squared \\
\hline Corrected Model & $5048,750^{\text {a }}$ & 4 & 1262,187 & 77,606 &, 000 &, 859 \\
\hline Intercept & 86,586 & 1 & 86,586 & 5,324 &, 025 &, 095 \\
\hline A * B & 3074,205 & 3 & 1024,735 & 63,006 &, 000 &, 788 \\
\hline X & 1045,678 & 1 & 1045,678 & 64,294 &, 000 &, 558 \\
\hline Error & 829,464 & 51 & 16,264 & & & \\
\hline Total & 297624,000 & 56 & & & & \\
\hline Corrected Total & 5878,214 & 55 & & & \\
\hline a. R Squared $=, 859$ (Adjusted R Squared $=, 848)$ & & & & \\
\hline
\end{tabular}

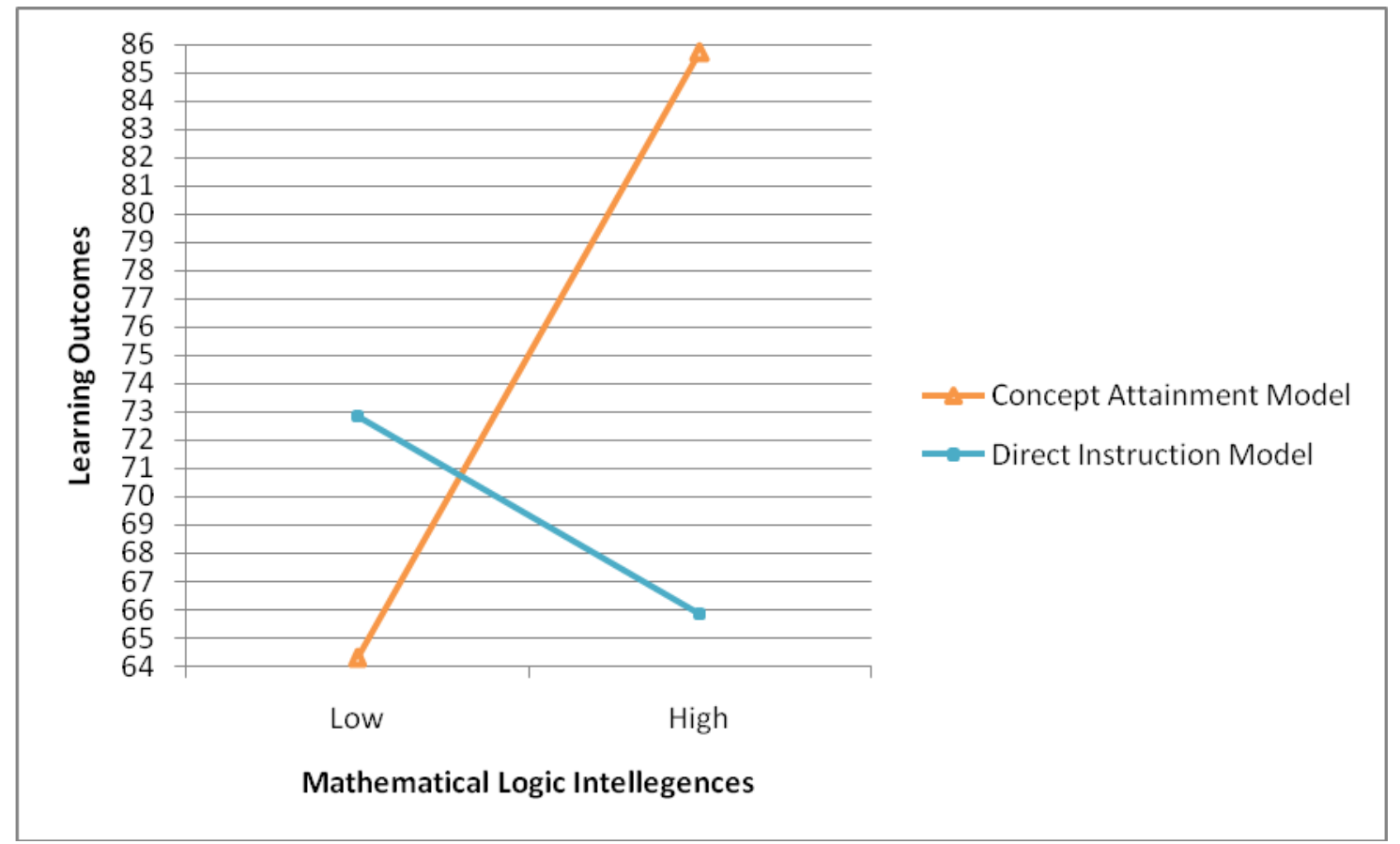

Figure 1. Effect of Interaction Between Learning Models and Mathematical Logic Intelligence Against Basic Chemistry Learning Outcomes After Controlling Initial Ability

Based on Figure 1 can be seen that students' essential chemistry learning outcomes taught by the concept achievement learning model. The students have high mathematical, logical intelligence after controlling the initial ability which connected with a straight line on the primary chemistry learning outcomes of students are taught with the concept achievement learning model in students has low mathematical. Logical intelligence after controlling the initial ability intersect with the line that connects the primary chemistry learning outcomes that taught with direct learning models in groups of students, have high mathematical. Logical intelligence after controlling initial abilities and primary chemistry learning outcomes acquired with the model direct learning in groups of students who have low accurate, consistent knowledge. It indicates that descriptively and visually illustrates that there is an interaction effect between learning models and mathematical intelligence on essential learning outcomes after controlling initial abilities. The results of the analysis of the estimated parameters and the mean deviation of the learning outcomes variable $(\mathrm{Y})$ according to the treatment group $\left(A_{1} B_{1}-A_{2} B_{1}\right)$ presented in Tables 5 and Table 6. 
Table 5. Results of parameter estimation analysis

\begin{tabular}{|c|c|c|c|c|c|c|c|}
\hline \multicolumn{8}{|c|}{ Dependent Variable: $\mathrm{Y}$} \\
\hline \multirow{2}{*}{ Parameter } & \multirow{2}{*}{ B } & \multirow{2}{*}{ Std. Error } & \multirow{2}{*}{$\mathrm{T}$} & \multirow{2}{*}{ Sig. } & \multicolumn{2}{|c|}{ 95\% Confidence Interval } & \multirow{2}{*}{ Partial Eta Squared } \\
\hline & & & & & Lower Bound & Upper Bound & \\
\hline Intercept & 22,323 & 6,394 & 3,491 & 001 & 9,487 & 35,159 & ,193 \\
\hline$[\mathrm{A}=1,00] *[\mathrm{~B}=1,00]$ & 1,300 & 2,098 & 620 &, 538 & $-2,911$ & 5,512 & 007 \\
\hline$[\mathrm{A}=1,00] *[\mathrm{~B}=2,00]$ & $-8,626$ & 1,524 & $-5,659$ &, 000 & $-11,686$ & $-5,566$ &, 386 \\
\hline$[\mathrm{A}=2,00] *[\mathrm{~B}=1,00]$ & $-17,303$ & 1,994 & $-8,679$ & ,000 & $-21,305$ & $-13,301$ &, 596 \\
\hline$[\mathrm{A}=2,00] *[\mathrm{~B}=2,00]$ & $0^{\mathrm{a}}$ & . & . & . & . & . & . \\
\hline $\mathrm{X}$ & ,763 & ,095 & 8,018 &, 000 &, 572 & ,954 &, 558 \\
\hline
\end{tabular}

Table 6. Average $\mathrm{Y}$ deviation of treatment group $\left(\mathrm{A}_{1} \mathrm{~B}_{1}-\mathrm{A}_{2} \mathrm{~B}_{1}\right)$

\begin{tabular}{|c|c|c|c|}
\hline & $\mathrm{A}=1$ & $\mathrm{~B}=2$ & Difference \\
\hline $\mathrm{A}=1$ & $\mu_{11}=\gamma_{0}+0,763 \mathrm{X}$ & $\mu_{21}=\gamma_{0}+\gamma_{3}+0,763 \mathrm{X}$ & $\gamma_{3}=\mu_{21}-\mu_{11}$ \\
\hline $\mathrm{A}=2$ & $\mu_{12}=\gamma_{0}+\gamma_{2} 0,763 \mathrm{X}$ & $\mu_{22}=\gamma_{0}+\gamma_{3}+0,763 \mathrm{X}$ & - \\
\hline Difference & $\gamma_{2}=\mu_{12}-\mu_{11}$ & - & - \\
\hline
\end{tabular}

Based on the Table 5, I have obtained, $H_{0}: \gamma_{3} \leq 0$ rejected, because the coefficient of $\gamma_{3}$ is definite such that $t_{0}=8,018>$ $\mathrm{t}_{\mathrm{t}(0.05 ; 49)}=1,70$. Thus the learning outcomes of basic chemistry taught by the learning model of concept achievement are higher than those learned by the direct learning model for groups of students who have high mathematical, logical intelligence after controlling the students' initial ability.

The results of the analysis of the estimated parameters and the mean deviation of the learning outcomes variable (Y) of the treatment group $\left(\mathrm{A}_{1} \mathrm{~B}_{2}-\mathrm{A}_{2} \mathrm{~B}_{2}\right)$ presented in Tables 7 and Table 8.

Table 7. Results of analysis of estimated parameters

\begin{tabular}{|c|c|c|c|c|c|c|c|}
\hline \multicolumn{8}{|c|}{ Parameter Estimates } \\
\hline \multicolumn{8}{|c|}{ Dependent Variable: Y } \\
\hline \multirow{2}{*}{ Parameter } & \multirow{2}{*}{ B } & \multirow{2}{*}{ Std. Error } & \multirow{2}{*}{$\mathrm{T}$} & \multirow{2}{*}{ Sig. } & \multicolumn{2}{|c|}{ 95\% Confidence Interval } & \multirow{2}{*}{ Partial Eta Squared } \\
\hline & & & & & Lower Bound & Upper Bound & \\
\hline Intercept & 64,338 & 9,528 & 6,752 &, 000 & 45,218 & 83,457 & ,467 \\
\hline$[\mathrm{A}=1,00]$ & $-78,331$ & 13,554 & $-5,779$ &, 000 & $-105,529$ & $-51,133$ & ,391 \\
\hline$[\mathrm{A}=2,00]$ & $0^{\mathrm{a}}$ & . & . & . & . & . & . \\
\hline$[\mathrm{A}=1,00] * \mathrm{X}$ & 1,206 &, 130 & 9,302 &, 000 &, 945 & 1,466 & ,625 \\
\hline$[\mathrm{A}=2,00] * \mathrm{X}$ &, 069 & , 130 &, 531 &, 598 &,- 191 &, 329 & ,005 \\
\hline
\end{tabular}

Table 8. Average $\mathrm{Y}$ deviation of treatment group $\left(\mathrm{A}_{1} \mathrm{~B}_{2}-\mathrm{A}_{2} \mathrm{~B}_{2}\right)$

\begin{tabular}{|c|c|c|c|}
\hline & $\mathrm{G}=2$ & $\mathrm{G}=1$ & Difference \\
\hline $\mathrm{B}=2$ & $\mu_{11}=\beta_{0}+\beta \mathrm{i}+0,069 \mathrm{X}$ & $\mu_{21}=\beta_{0}+\beta_{2}+0,069 \mathrm{X}$ & - \\
\hline $\mathrm{B}=1$ & $\mu_{12}=\beta_{0}+\beta_{3}+0,069 \mathrm{X}$ & $\mu_{22}=\beta_{0}+0,069 \mathrm{X}$ & $\beta_{3}=\mu_{12}$ \\
\hline Difference & - & $\beta_{2}=\mu_{21}-\mu_{22}$ & - \\
\hline
\end{tabular}


Based on the Table 7 and Table 8 obtained $\mathrm{H}_{0}: \beta_{3} \leq 0$ accepted, because based on the hypothesis, the coefficient $\beta_{3}$ is negative so $t_{0}=0,531<t_{t(0.05,49)}=1.70$. Thus the learning outcomes of basic chemistry taught by the learning model of concept achievement are lower than those learned by direct learning models for groups of students who have high mathematical, logical intelligence after controlling the students' initial abilities.

\section{Discussion}

The results of the analysis of covariance analysis (Table 4) obtained the value of $F_{\text {count }}\left(F_{0}\right)=21,301$ higher than $\mathrm{Ft}$ $(0.05 ; 3 / 51)=4,08$. It means that there are differences in essential chemistry learning outcomes between groups of students who taught with the Learning Model of Achievement of Concepts and those that Learned with the Direct Learning Model, after controlling students' initial abilities.

Based on descriptive analysis, students' essential chemistry learning outcomes taught by the learning model of concept achievement have an average of 75 . while the learning outcomes of primary chemistry students who are motivated by direct learning have an average of 69,36 . It confirms that the essential chemistry learning outcomes of students taught with the learning model of the concept achievement are higher when compared to the basic chemistry learning outcomes of students are shown with the learning model directly after controlling initial abilities. It can be visually illustrated in Figure 2.

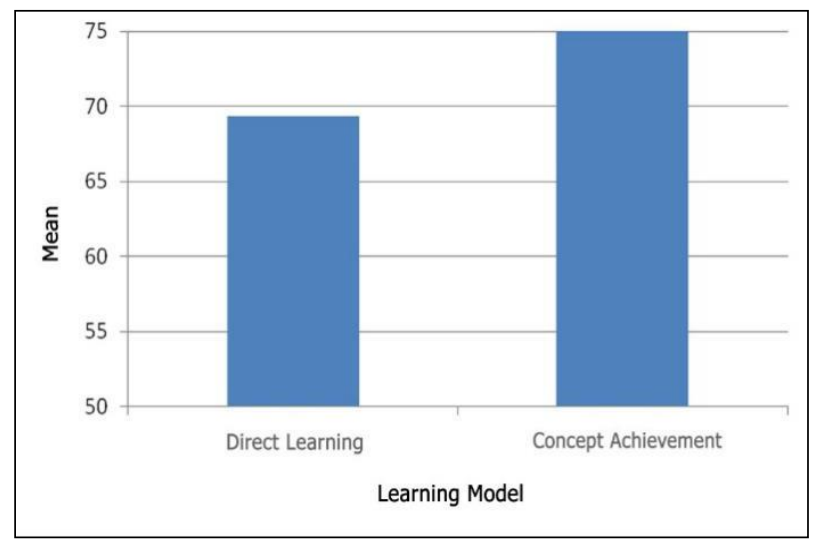

Figure 2. Differences in Basic Chemistry Learning Results In Groups A1 And A2 After Controlling Initial Ability

From Figure 2, it can be seen that the Basic Chemistry Learning Outcomes of Students Learned with the Learning Model The achievement of the concept is higher than that of Students Learned with the Direct Learning Model.

The concept achievement learning model is a flow of constructivism learning theory that focuses on developing the ability of students to build or construct their new knowledge through the thought process of synthesizing old and new knowledge and experience. Also, the concept achievement learning model based on the view that learners or students build their understanding of the topics they are learning rather than recording lessons in a systematically organized form. In determining the achievement of concepts, students designed to distinguish appropriate examples from incorrect examples from the various categories presented, analyze ideas, develop concepts, and gain concepts. According to [18] concept achievement learning model is a strategy that allows students to explore critical concepts actively and deeply, by examining examples and no examples of the provided ideas, students construct their understanding from 'bottom to top,' test and perfect their knowledge of concepts and critical nature until it becomes permanent. In other words, in learning the achievement of concepts, students construct their understanding, test, perfect understanding of concepts, analyze ideas, and make understanding concepts relatively permanent. It supported by [10] research, which found that students are more motivated and ready to learn through the learning model of concept achievement. It means that students who taught with the concept learning model are more prepared to construct their understanding so that it is relatively permanent compared to the deductive learning model, such as the direct learning model. As a result, the learning outcomes of students who taught with the learning model the achievement of the concept will be higher than the learning outcomes of students who learned with the direct learning model.

Based on the report, it explained that the concept achievement learning model is very suitable when applied in essential chemistry learning. For example, students comparing the properties of one element with other elements, studying its characteristics, exploring its uses, and predicting its reactivity. Then students can predict what happens if one part reacted with another factor this learning, students would try to combine facts, concepts, and generalizations into one systematic building of knowledge. Therefore students are expected to understand the relationship between these topics supported by the expertise and experience they had before. In contrast to the concept achievement learning model, in the direct learning model, the lecturer delivers the subject matter directly, step by step; In this direct learning model, the role of the lecturer is more dominant, so that lecturer is the only source of information in learning. Meanwhile, the involvement of students in the direct learning model is very lacking or tends to be passive because, In the immediate learning process, students are limited to the activities of receiving, seeing, observing, understand, and conclude the material presented directly.

The learning format in the direct learning model is the lecturer delivering the subject matter in a structured way by explaining concepts and procedures. To check student understanding, lecturers provide guided training and independent training. Learning with a direct learning model does not facilitate students to find their knowledge based 
on experience, it is enough to wait for the information conveyed by the lecturer so that they are required to understand. Based on the information, learning achievement of the concept more encourages students to build their knowledge actively by linking various facts, rules, ideas that they already have with new information they get and then proceed to develop hypotheses and make conclusions through scientific procedures. In this line with what was stated by [19], "the concept attainment model involves students applying inductive reasoning to determine the idea presented by the teacher through examining several positive and negative examples of the concept."

The concept achievement learning model involves students applying inductive reasoning to determine the ideas the teacher presents by examining positive and negative examples of concepts. In contrast to students taught with direct learning models that tend to be passive and tend to facilitate students less to find their knowledge based on experience. Thus, theory and facts are very appropriate that the results of learning basic chemistry between students learning with the learning model of achieving concepts are higher than students learning with a direct learning model after controlling initial abilities. Based on the analysis of variance to test (Table 4), the interaction between treatments, was it found that the value of $\mathrm{F}_{0}(63,006)$ with> $\mathrm{Ft}_{(0.05 ; 3 / 51)}(2,85)$ with a probability of $0.000<$ alpha $(5 \%)$. It indicates that $\mathrm{H}_{0}$ rejected so that the conclusion there is an influence of interaction between learning models and mathematical, logical intelligence in influencing essential chemistry learning outcomes, after controlling the initial abilities of students. The quality of the learning process is very influential on the learning outcomes produced. The quality of the learning process will be good if it is well designed, planned deliberately, set using the right media and learning models according to class conditions, material characteristics, and characteristics of students. The selection of an appropriate learning model must accommodate the features of different students.

Students with mathematical logic are students who can use or process numbers, classify, perform mathematical operations, analyze causal relationships, hypothesize, and conclude. According to [20][21] precise, logical intelligence contains a person's ability to think inductive and deductive. Students have highly accurate, consistent information will fit in with inductive learning, while students have low mathematical, logical intelligence will match with inductive knowledge. In inductive learning, the lecturer presents some properties or characteristics of a particular compound or phenomenon, then students identify, construct, classify until finally they can interpret or conclude themselves. So in inductive learning begins with specific facts or concepts and ends with general ideas. In other words, inductive learning is learning from specific to general. One of the inductive learning models is the concept learning model. In the concept learning model, lecturers present facts, positive and negative examples that are labeled, then students have presented examples that are not marked, students provide hypotheses, test hypotheses, and conclude. Based on the explanation, if students have high mathematical, logical intelligence taught with the concept of learning achievement model. A learning process will be formed, which forms students can construct new knowledge combined with their previous knowledge and experience so that students will have significant learning outcomes.

Conversely, for students who have low mathematical, logical intelligence will be more suitable to be taught by learning that is deductive. One of the deductive learning models is direct learning. In direct knowledge, the teacher presents the material systematically in stages, so that students have low mathematical, logical intelligence live to accept what is given by the teacher and are more "comfortable" and motivated to participate in direct learning. So the learning outcomes will be higher compared to students who have high mathematical, logical intelligence. Thus, it can be said there is an interaction effect between the learning model and mathematical, consistent knowledge of students' essential chemistry learning outcomes. Based on the analysis (Table 5) of the estimated parameters and the mean deviation of the learning outcomes variable $(\mathrm{Y})$ according to the treatment group $\left(A_{1} B_{1}-A_{2} B_{1}\right)$, it found that $H_{0}: \gamma_{3}<0$ rejected because based on the hypothesis, the coefficient of $\gamma_{3}$ is definite such that $t_{0}=8,018>t_{t(0.05 ; 49)}=1,70$. Thus it can be concluded that the essential chemistry learning outcomes of students taught with the concept learning model achievement (mean 85,71) are higher than those shown by the direct learning model (average 65.86) for groups of students who have high mathematical, logical intelligence after controlling initial ability. Differences in learning outcomes for groups of students have high mathematical, logical intelligence visually illustrated in Figure 3.

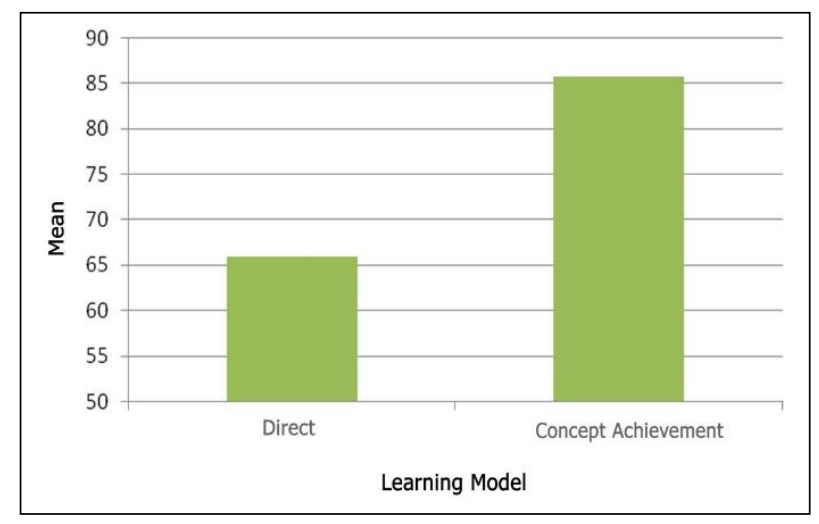

Figure 3. Differences in Learning Outcomes For Student Groups High Mathematical Logic Intelligence $\left(B_{1}\right)$

Figure 3 explains that the learning outcomes of basic chemistry taught by the learning model of concept 
achievement are higher than that of students who are motivated by direct learning models for students with high mathematical, logical intelligence after controlling students' initial abilities. Students with high mathematical, logical intelligence end to enjoy learning activities related to material counts or related to materials that require top critical thinking skills such as chemical kinetics, solution colligative properties, $\mathrm{pH}$ of acid and base solutions, $\mathrm{pH}$ of buffer solutions, $\mathrm{pH}$ of hydrolysis, and solubility. The product of solubility and the redox reaction equation. To understand the topic, for example, the outcome of solubility, the student must be able to: (a) calculate the concentration of the solution, (b) determine the type of salt and base solution, (c) write down the ionization reaction of weak bases and salts that are difficult to dissolve, and (d) solve mathematical equations.

Based on the classification (Figure 3 dan Table 4), it can be explained that the potential for mathematical, logical intelligence possessed by students is significant because it can facilitate students to learn material related to numbers or documents that require very high understanding. Learning that applies the concept achievement model is very much by the characteristics of the content presented. Namely, kinetics, solutions, and redox reaction equations that can foster the ability to think logically, develop the ability to solve problems, use mathematical operations and analyze causal relationships.

Thus the essential chemistry learning outcomes of students taught with the concept learning model are higher than the learning outcomes of primary chemistry students are driven by direct learning models for students who have high mathematical, logical intelligence. It is because in the learning process with the direct learning model, the role of lecturers is more dominant, students tend to be less active and take more notes. It supported by [22], which states that one of the weaknesses of the direct learning model is that it does not motivate students to be actively involved in learning. It means that for students who have high logical intelligence, it is more suitable to be taught with the concept of learning achievement models compared to the direct learning model. It is also in line with [19] stated that the concept learning model involves students using critical thinking and metacognition skills. Furthermore, [23] explains that "concept Attainment is an instructional model that promotes inductive-thinking processes. " It means that the concept achievement learning model is an inductive learning model that matches the characteristics of students who have high mathematical, logical intelligence.

Based on the analysis (Table 7) of the estimated parameters and the mean deviation of the learning outcomes variable $(\mathrm{Y})$ according to the treatment group $\left(A_{1} B_{2}-A_{2} B_{2}\right)$, it found that $H_{0}: \beta_{3} \leq 0$ accepted, because based on the hypothesis, the coefficient $\beta_{3}$ is negative so $t_{0}$ $=0,531<\mathrm{t}_{\mathrm{t}(0.05,49)}=1.70$. Thus it can be assumed that the essential chemistry learning outcomes learned by the concept learning model achievement (Mean 64,29) are lower than those determined by the direct learning model (average 72,86) for groups of students who have high mathematical, logical intelligence after controlling ability the beginning of students who can visually be through identified Figure 4.

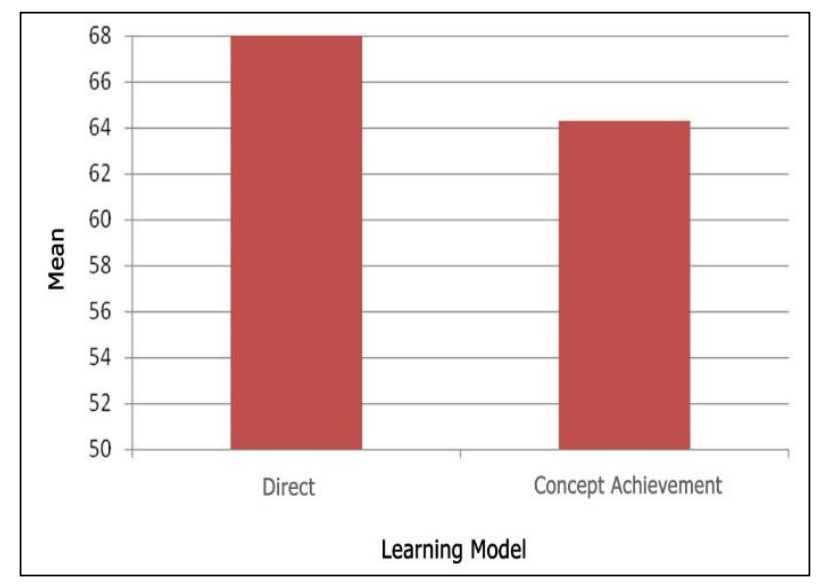

Figure 4. Differences in Learning Outcomes For Student Groups Low Mathematical Logic Intelligence $\left(\mathrm{B}_{2}\right)$

The results (Table 5 and Figure 4) analysis inform that the basic chemistry learning outcomes learned with the learning achievement concept model are lower than those acquired with the direct learning model for students who have low mathematical, logical intelligence after controlling the initial abilities of students. Thus hypothesis 4 can be accepted. Students have low mathematical logic intelligence taught with a direct learning model, in general, their learning outcomes will be better than students are trained with learning models to achieve concepts that have low mathematical, logical intelligence. This because the characteristics of students who have in-depth mathematical, valid knowledge tend to depend more on the direction and explanation of the lecturer in the learning process. Students have little accurate, consistent information in the learning process with the direct learning model benefit more because the learning model material will be accepted directly without having to construct new knowledge. While students with high mathematical logic tend to be active and like constructive and exploratory activities will then become bored, lazy, and not motivated in the learning process so that it will have an impact on the learning outcomes obtained.

The findings (Figure 4) are in line with was stated by [24][25] that "direct instruction to be more effective for students with learning disabilities, direct learning is more compelling given to students have learning disabilities. It means that the lower the ability of students to explore knowledge, the more effective direct learning is applied. In other words, students have little mathematical, logical intelligence will be more effective in learning with the direct learning model compared with the learning achievement concept model. 
Therefore the results are consistent with the findings that the essential chemistry learning outcomes taught by the learning model of the concept achievement are lower than the students learned by the Direct learning model for students who have low mathematical, logical intelligence.

\section{Conclusions}

Based on the results and discussion described, the resulting conclusions can be a draw : (1) Overall, there are significant differences in essential chemistry learning outcomes between students taught with the concept learning model, and those are motivated by direct learning after controlling for initial abilities. (2) There is an interaction effect between learning models and mathematical, logical intelligence on learning outcomes of basic chemistry after controlling for initial abilities. (3) The essential chemistry learning outcomes of students taught with the learning model of concept achievement are higher than those learned by the direct learning model after controlling the initial ability for groups of students who have high mathematical, logical intelligence. (4) The essential chemistry learning outcomes of students taught with the learning model of concept achievement are lower than those shown by the direct learning model after controlling initial abilities for groups of students have low mathematical, logical intelligence

\section{Acknowledgements}

The author would like to thank the graduate school of Universitas Negeri Jakarta for all their support during the research process, the gratefully also to the Chair of Doctoral Program in Department of Technology Education his help so that this research can be resolved. Moreover, especially for the Halu Oleo University for all forms of support so that the author can finish this dissertation. We are very grateful to experts for their appropriate and constructive suggestions from the reviewer.

\section{REFERENCES}

[1] L. Darling-Hammond et al., "Implications for educational practice of the science of learning and development," Applied Developmental Science, vol. 0, no. 0, pp. 1-44, 2019.

[2] L. Taylor and J. Parsons, "Improving student engagement," Current Issues in Education, vol. 14, no. 1, pp. 1-33, 2011.

[3] N. J. Mccormick, L. M. Clark, and J. M. Raines, "Engaging students in critical thinking and problem solving: a brief review of the literature," Journal of Studies in Education, vol. 5, no. 4, pp. 100-113, 2015.
[4] M. Killian and H. Bastas, "The Effects of an active learning strategy on students' attitudes and students ' performances in introductory sociology classes," Journal of the Scholarship of Teaching and Learning, vol. 15, no. 3, pp. 53-67, 2015.

[5] J. A. C. Hattie and G. M. Donoghue, "Learning strategies : a synthesis and conceptual model," Nature Publishing Group, vol. 1, no. December 2015, pp. 1-13, 2016.

[6] A. Kumar and M. Mathur, "Effect of concept attainment model on acquisition of physics concepts," Universal Journal of Educational Research 1, vol. 1, no. 3, pp. 165$169,2013$.

[7] V. Sood, "Effect of mastery learning strategies on concept," International Journal of Behavioral Social And Movement Sciences, vol. 02, no. April, pp. 144-155, 2013.

[8] P. Bala, "Effect of mastery learning approach (MLA ) on the achievement in mathematics of students with mathematical difficulties," IOSR Journal of Humanities And Social Science (IOSR-JHSS), vol. 24, no. 5, pp. 29-35, 2019.

[9] A. Fjortoft et al., "The effects of two direct instruction teaching procedures to basic skills to two students with disabilities," Multidisciplinary Journal of Educational Research, vol. 4, no. 2, pp. 151-182, 2014.

[10] R. Bhargava, "Effect of concept attainment model on achievement in social sciences," International Journal of Science and Research, vol. 5, no. 5, pp. 2015-2017, 2016.

[11] A. M. Suleiman, "Concept attainment teaching methodology (CATM ) - an effective approach for training workers on chemicals health hazards," Universal Journal of Educational Research, vol. 4, no. 11, pp. 2677-2685, 2016.

[12] G. Latchanna and K. Swarnalatha, "Effect of concept attainment and inquiry training model in teaching biological," MIER Journal of Educational Studies, Trends \& Practices, vol. 6, no. 1, pp. 110-124, 2016.

[13] D. S. Kauts and N. Kaur, "Effectiveness of concept attainment model on academic achievement in science in relation to cognitive styles among ix grade students," International Journal of Scientific Research and Reviews, vol. 8, no. 1, pp. 1773-1786, 2019.

[14] A. Khataybeh, "Multiple intelligences of students at Jordanian universities," Journal of International Education Research, vol. 7, no. 4, pp. 1-13, 2011.

[15] A. Said and A. Budimanjaya, 95 Strategi mengajar multiple intelligences. Jakarta: Prenadamdia Group, 2016.

[16] Sugiyono, Metode penelitian pendidikan pendekatan kuantitatif, kualitatif dan R \& D. Bandung: Alfabeta, 2012.

[17] S. J. Osterlind, Constructing test items: multiple-choice, constructed-response, performance, and other formats. New York: Kluwer Academic Publishers, 2002.

[18] S. Perini, R. Luglietti, M. Margoudi, M. Oliveira, and M. Taisch, "Computers in industry learning and motivational effects of digital game-based learning ( DGBL ) for manufacturing education - the life cycle assessment ( LCA) game," Computers in Industry, vol. 102, pp. 40-49, 2018.

[19] J. R. Mayer, "Effects of using the concept attainment model with inductive reasoning with high school biology students," 
Montana State University, 2012.

[20] H. B. Uno and N. Mohamad, Belajar dengan pendekatan PAILKEM. Jakarta: Bumi Aksara, 2014.

[21] H. Gardner, Multiple Intelligences : New Horizons in Theory and Practice, Revised. New York, United States: INGRAM PUBLISHER SERVICES US, 2006

[22] Hramiak, Alison, and T. Hudson. Understanding learning and teaching in secondary schools. New York: Routledge, 2011.

[23] D. Mcdonald and H. Clear, "Concept attainment : instruction suitable for all," Academic Exchange Quarterly Summer, vol. 19, no. 2, pp. 1-8, 2015.

[24] R. Gersten and C. Darch, "Direct instruction: a researchbased approach to curriculum design and teaching," vol. 53, no. 1, pp. 17-31, 1986.

[25] D. Zhang, "Effects of visual working memory training and direct instruction on geometry problem solving in students with geometry difficulties," Learning Disabilities: A Contemporary Journal, vol. 15, no. 1, pp. 117-138, 2017. 